\title{
Cleavages in the Post-Communist Countries of Europe: A Review
}

\author{
ENA REDŽIĆ AND JUDAS EVERETT
}

\section{Sciendo}

Politics in Central Europe (ISSN: 1801-3422)

Vol. 16, No. 1

DOI: 10.2478/pce-2020-0011

\begin{abstract}
This review of the historical studies of cleavages and seeks to bridge the gap between the historical study of cleavages and frozen cleavage theory and the post-communist states of Europe which have transitioned to democracy. The study identifies the literature on frozen cleavages and new divides which have arisen transition, as well as the primary actors in their political representation and issue positioning. The key literature in the development of studies on cleavages was provided by Lipset and Rokkan, but their work focused mostly on Western democracies and did not include any of the countries which were behind the iron curtain at the time. However, the transition of the post-communist nations of Europe are now several decades old. Since the demise of communist regimes in Europe, much literature has been produced on the newly democratic regimes developing there. This article provides a broad overview of general trends in cleavage literature and more specific developments for Bulgaria, Croatia, Czech Republic, Hungary, Poland, Romania and Slovakia. The main findings were that there are frozen cleavages present in the post-communist countries of Europe, but that much of the developments since the fall of communism seem to be unpredictable and changeable - a fact reflected by the instability and constant change in the party systems.
\end{abstract}

Keywords: social cleavages, political divisions, post-communist transitions, comparative politics

\section{Introduction}

This article seeks to better understand the cleavages in the post-communist countries of Europe and bridge the gap between academia focused on these cleavages and Lipset and Rokkan's (1967) seminal work 'Cleavage Structures, 
Party Systems, and Voter Alignments'. There is a particular focus on the frozen or unfrozen nature of the cleavages in the selected countries, as well as political parties' ability to remain relevant despite potential changes in cleavages. Frozen cleavage theory can be traced back to the aforementioned Lipset and Rokkan (1967) study, where cleavages were defined as having three central characteristics. Firstly, a cleavage involves a kind of social division which separates people by socio-cultural or socio-economic characteristics. Secondly, those involved in this division must be aware that they are, they must be self-aware of their collective identity and willing to act on the basis of that collective identity. Thirdly, and finally, a cleavage must also be expressed in organisational terms, through political parties or interest groups for example.

Cleavage theory has produced a huge amount of literature and has been an influential element of the development of political science. This article presents an overview of some of the most important works on the following countries: Bulgaria, Croatia, Czech Republic, Hungary, Poland, Romania and Slovakia. In seeking to bring together a considerable amount of literature on the cleavages in the post-communist countries of Europe and ask pertinent questions about the relationship between the frozen cleavage theory, the development of the literature on the selected cases and the present reality of these countries, this article seeks to bridge the gap between the seminal Lipset-Rokkan study and the reality of three decades of academic development on the topic, since the demise of communist regimes. The logic at the heart of probing in the direction of frozen cleavage theory is, naturally, to clearly and explicitly illuminate the political reality across a broad range of countries and to attempt to understand whether across the post-communist and transitional experience parties have successfully and consistently been able to provide representation on the basis of real existing cleavages.

The Most Similar System Design (MSSD) stands out as a highly suitable framework of the comparative method of the present study. Lijphart's (1971) work 'Comparative Politics and the Comparative Method', traced the comparative method all the way back to John Stuart Mill, ${ }^{1}$ more specifically we follow the Anckar's (2008) 'looser interpretation of MSSD'. ${ }^{2}$ All of these countries are EU member states, with either fully proportional or mixed, in the case of Hungary,

1 Other notable pieces of scholarship, such Przeworski and Teune's The Logic of Comparative Social Inquiry have noted the long tradition of seeking as objects those which are as similar as possible in order to maximise the usefulness in comparing them - especially in finding causality. Theodore W. Meckstroth noted that whether the form of comparative method employed is conceived as the most similar or most different systems design, what is vitally important is the presence of well-formed concepts, hypotheses, and theories which encompass any and all variables whose explanatory importance is to be evaluated.

2 It involves choosing countries that appear similar in as many background characteristics as possible, while a strict application involves choosing countries that are similar in a number of specified variables, leaving only one aspect as different. 
electoral systems. Moreover, all of these countries are ranked free or partly free by Freedom House (2019) and all have either average Democracy Scores (DS) or better as per the Nations in Transition report also by Freedom House (2018).

The numerous and significant similarities between these countries does not mean to suggest that their historical experiences have been identical, naturally there were differences between the various interpretations of communist ideology in each of the former communist countries, especially following the death of Stalin, which led to more ideological diversity (Brzezinski 1957). Nonetheless, most scholars make a very clear distinction between the twelve former union republics of the Soviet Union who were internationally recognized to be so, and the Baltic States and Eastern Europe (Beissinger - Kotkin 2014), these states experienced a shorter period of communist rule and more experience with free trade and western partners - most famously via the New Economic Mechanism and Goulash Communism (Kornai 1996). Hence, former USSR countries are excluded from consideration.

EU membership status has been taken as the second criteria for case selection. Much research has been produced on the effects of EU conditionality on the transitioning post-communist countries of Europe, with a large amount of this research focusing on the effectiveness of EU conditionality as a mechanism (Schimmelfennig - Sedelmeier 2004). The ability of a country to successfully become an EU member state, meeting all the entailed conditions and requirements, can be seen as incredibly strong concrete evidence of the state's level of democratic consolidation, economic success and level of stateness (Mrak Rojec 2013). There is also a need to acknowledge that smaller countries may have experienced successful transitions, but are not suitable for comparison with countries tens of times larger than themselves. As of June 2019 Poland had a declared population of 38,386,000 (Statistics Poland 2019), considering, and trying to compare, countries which are less than one tenth of the size would not be comparable in this case.

In analysing the existing literature on these countries special consideration will be given to whether or not the cleavages of post-communist Europe are frozen, this means that as in Lipset and Rokkan's study, cleavages which were present several decades earlier are reflected in the present party system. The possibility of different degrees of frozenness should not be overlooked, although may not be of central importance. Also under consideration is whether a persistence in the ideological axis is present despite evolving cleavages. Plainly, have parties representing the opposing sides of societal divisions in present today the same as the ones representing the division at the end of communist era? The specificity and more general changes since Lipset-Rokkan study should be retained at the forefront of minds as each nation is considered. Taking into account the transition period and the post-communist past the research identifies active social cleavages and their political representation. 
The study analyses the literature produced on the region, bridging the gap between the current situations and Lipset and Rokkan's work, a broad overview of the general existing literature is first critically engaged with, before addressing each case, one by one, providing the necessary context to understand the selected cases. The study identified a tendency for historical cleavages to be more likely to be frozen, with considerable changeability associated with newer cleavages and party systems across the region, where clear patterns of representation have not been fully crystallized even three decades after the communist demise.

\section{Review of the Theoretical Development of Studies of Cleavages}

A considerable body of literature exists on the topic of cleavages, the most notable being the aforementioned 'Cleavage Structures, Party Systems, and Voter Alignments' by Lipset and Rokkan. However, this was far from the first study which dealt with questions of voting behaviour and voter patterns. The roots of the research of electoral behaviour are in the Columbia Studies, beginning in the 1940s with Lazarsfeld, Berelson, and Gaudet (1944), followed by 'Voting: A Study of Opinion Formation in a Presidential Campaign' (Berelson et al. 1954). Followed by Dahl's (1956) 'A Preface to Democratic Theory' and a series of studies from the University of Michigan, notably 'The American Voter' both which argued that partisan loyalties were relatively stable, but by no means unchanging (Campbell et al. 1960).

Lipset and Rokkan's (1967) study concluded that with the introduction of universal suffrage and once cleavages are formed, institutionalized party systems freeze along the lines of division, creating a more or less permanent party system structure. The challengers to the theory of freezing hypothesis during 1970 signified the change in reality and academia alike (Nie - Petrocik - Verba 1999; Pedersen 1979). Later studies showcased the changes in the institutionalized party systems as well (Mair 1997; Dupré 2018). Mair, Müller and Plasser (2004) added that freezing hypothesis was applicable in the decades after the publication, but did not hold in the aftermath of social changes and movements in the West challenging the applicability of the freezing hypothesis in democracies.

The lack of a clear definition of cleavage in the Lipset and Rokkan study, combined with the ambiguity in the operational criteria for the freezing hypothesis allowed for a variety of conceptualisations of 'cleavage'. Bartolini and Mair's (2007: 216) conceptualisation of a cleavage encompasses three elements - an empirical, normative and behavioural - which must coexist in the same period and for which changes occur at the same time so that the cleavage can be seen „as a form of closure of social relationships “. While, for Bornschier (2010) cleavages represent a long-standing pattern of political behaviour of structurally defined groups. In their influential 'The Analysis of Political Cleavages', 
Rae \& Taylor (1970) describe three roles cleavages might take - a cleavage based on tribe, caste, or other socially constructed group; an opinion cleavage which refers to ideological divisions; and a cleavage seen through the voting patterns and joining division-based organisations.

Some long term cleavages, such as social class and religion, seem to have lost some of their power in society has led to a reduction in lifelong voter predictability which opposes the freezing hypothesis by Lipset and Rokkan (Hooghe Marks 2018). Dupré (2018) agreed with Mair (1997) that the cleavage once formed, and intensified by the institutional interaction with the social systems, freezes the party system along a specific division, while marginalizes, or ignores the rest of the issues. Posner (2005) argued for the minimum-winning-coalition approach, where elites tend to support the initiatives that allow them the highest gains while minimally sharing resources with others. Mair and Mudde (1998) suggested that individual parties can experience fundamental changes in the frozen party systems, while five years later concluded that religious identities are far from being fixed since societies are ever-changing, therefore if political alignments seem fixed, it is not due to constant cleavages (Mair 2003).

Significant work has been produced to identify different social and political conflicts. Bendix's (1952) Social Stratification and Political Power, mainly focused on Marxist, class based cleavages. Others, such as Donald Horowitz's (1985) 'Ethnic Groups in Conflict' or Posner's (2005) 'Institutions and Ethnic Politics in Africa' identify and analyse ethnic cleavages and their roles in shaping political institutions and conflicts, while Mylonas (2013) studied religious, and Sturm and De Haan (2015) ethnolinguistic political divides. The utilisation of geographical cleavages for understanding of the voting patterns has been used by R. P Woolstencroft (1980) in 'Electoral Geography: Retrospect and Prospect'.

In 2016 Hooghe and Marks (2016) identified three essential attributes of the cleavage theory: 1 . Former external forces in society can cause periodic breaks which then determine the party system; 2 . Parties have inflexible programs; and 3. new-rising parties imply the change in party systems. This relates to the work of Schattschneider and Adamany (1975) who observed that in the period of normal politics, the party system does not address new issues society is divided upon, because existing cleavages already organize the lines of divisions upon the issue. However, Bornschier (2010) followed slightly different logic, and assumed cleavages had an evolving nature - they remain stable however the issues that appear with time tend to be addressed through the same opposing sides of the persistent ideological axis. In the mainstream left study by Carvalho and Ruedin (2018), it is shown that in the west, parties stay loyal to their core ideologies. Hooghe and Marks (2016) conclude that the new issues on which society divides will be represented only by new challenger parties, not by the old established ones, which, as argued by Klingemann, Hans-Dieter Hofferbert and Budge (1994), are historical beings. Even specifically on the topic of cleav- 
ages and the party systems which exist around Eastern Europe a large amount of literature exists. The literature produced on cleavages in post-communist Europe tends to take a slightly ambiguous view on what exactly constitutes a cleavage. In 'Cleavages, Parties, and Voters: Studies from Bulgaria, the Czech Republic, Hungary, Poland, and Romania', cleavages are defined as „long-term structural conflicts that give rise to opposing political positions, which may or may not be represented by parties" (Lawson - Römmele - Karasimeonov 1999). Karasimeonov preferred a four-fold typology for Eastern Europe which identified four types of cleavages: historical, temporary (transitory), actual and potential. Whereby, residual (historical) cleavages are inherited from pre-communist society, temporary (transitory) cleavages are related to the period immediately after the fall of communism, actual cleavages relate to new cleavages created by post-communist reforms, and potential cleavages are those which may transform into actual cleavages in the new economic and political system (Karasimeonov - Lyubenov 2013: 408).

Not all experts in the field find the concept of political cleavage useful for the post-communist world (White - Rose - McAllister 1997; Elster et al. 1998). On the contrary, Lijphart seems to take the concept as given and states that the existence of cleavages allows the strengthening of the party-public relations, gives rise to democratic stability and increases the predictability of political outcomes (Lijphart - Rogowski - Weaver 2010). Fukuyama (2006: 418) has completely dismissed the existence of cleavages in the region and argued that the end ideological competition ${ }^{3}$ and the victory of liberalism marked the end of political cleavages which have been active during the industrial era, anticipating only the conflict between the winners and losers of transition. More recently, Hloušek and Kopeček (2008) highlighted the notable fluctuations in party identities and the frequent changes in the party composition ${ }^{4}$ of government coalitions in the post-communist East-Central Europe political parties, which were arguably affected by the political and economic transition during the 1990s, as well as the legacy of both, communist and pre-communist history. Robert Rohrschneider and Stephen Whitefield (2009) found that in the case of CEE countries there was considerable literature to suggest that early in the transitions there were no coherent party cleavages; there was one single ideological cleavage in the region as a whole, which was support for and opposition against liberal regime change; and, that a number of common cleavages across the region supplemented by some national specificities existed.

The post-communist context has some considerable differences from the kind of context which Lipset and Rokkan were considering. More to it, significant

3 Between liberalism and communism.

4 They add that though parties can be flexibly to some extent they almost never position themselves at the new conflict dimension. 
literature has been produced since this study and that even the countries of that original study have undergone significant change. The literature indicates that if stability in the cleavages and party systems of post-communist Europe are lacking it may well be due to general changes, alternatively it has also been indicated that it may be the unique position of these countries.

\section{Case-based identification of cleavages}

\section{Bulgaria}

Karasimeonov and Lyubenov (2013: 421) have noted that in the Bulgarian case social and political cleavages experienced a complete reversal during the communist era. Traditionally the main cleavage in Bulgaria was one of urban versus rural, but this was changed by the seizing of power by communists who put class at the forefront of all politics. Initially, like most post-communist states, the major divide within society was one of communism versus anti-communism, deeply entrenched enough for it to be considered a cleavage, according to Karasimeonov and Lyubenov the salience lasted from 1990 to 2001. In the political party the reformers were represented by the Union of Democratic Forces (SDS) and those with a more cautious approach to change were grouped in and around the communist party Bulgarian Socialist Party (BSP) (Karasimeonov - Lyubenov 2013: 409). However, later Rohrschneider and Whitefield (2009) found that the three most important cleavages in Bulgaria were welfare, economic regime and the democracy dimension. This indicates that issues which most would consider to be directly connected to post-communist transition remained salient even in 2008 as well as connected with the amount of corruption in Bulgaria, a regular focus of research studies (Gawthorpe 2010). In 2015, Moreno (2015: 133) noted that the socio-economic dimension neatly resembles the Western template.

An enduring cleavage however exists between the ethnic Bulgarians and Turkish minority. The rise of the mainly Turkish party DPS (The Movement for Rights and Freedoms) has not gone unnoticed by the Bulgarian majority and has on occasion led to some conflict in society (Ganev 2004). There have also been accusations of interference from Turkey in Bulgarian elections (Cheresheva 2017). This may have returned deep-rooted feelings to the surface, as Bulgaria was so close to the heart of the Ottoman Empire the fighting was particularly fierce, but liberation was only secured by the Russo-Turkish war (Lawson - Römmele - Karasimeonov 1999). As such Russia and Turkey have traditionally occupied a special place in the political understanding of the world of Bulgarians. During communist rule there was even a proposal to join the Soviet Union as another Soviet Republic, although there was little encouragement for this from Moscow (Bideleux - Jeffries 2007: 88). 
The importance of Russia has not entirely disappeared from Bulgaria but the role has diminished and Turkey, the Turkish minority and relations between them and Bulgaria has ascended to one of undoubted importance. The impact of Turkey's Presidency of Religious Affairs (Diyanet) on Bulgaria has also not gone unnoticed, although the Bulgarian state has resisted the urge to attempt to directly finance or control the Bulgarian Grand Mufti's office (Öztürk - Sözeri 2018). Bulgaria's relationship with its more powerful neighbours has been an important element of Bulgarian identity and politics for centuries but this has not been particularly stable and due external change, be that of the Ottoman Empire, Russian Empire or USSR - who all collapsed - or modern day Turkey which is becoming more assertive and looking for different foreign policy tools, as important neighbours change this often has important ramifications for Bulgaria and Bulgaria's internal politics and identity.

The relationship with Muslims and Turkish people is complicated by the actions of the Turkish state, but the relationship with The Roma does not exactly suffer from the same complications. The Roma community has been reported to suffer from much worse health conditions, ghettoisation and being forced to the economic outskirts (Nenkova 2013). Their otherisation through education has been documented (Lambrev - Traykov - Kirova 2018) as has their traditional and historical viewing of Roma as 'alien' (Cviklova 2015). Having joined the European Union and ratified the ECHR Bulgaria still does not live up to the anti-discrimination norms expected from such a state. Like many transitioning European nations, the role of the EU in Bulgaria is one of undoubted importance, even if it will take considerable time to fully understand the impact. While the elites of Bulgaria still lack some of the skills and expertise required to fully tackle problems like corruption, the EU has had a sizeable impact especially on the speed of change in Bulgaria (Kostova 2016). However, as of yet the othering and alienation of Roma has been persistent and shows no signs of abating.

Most persistent cleavages in Bulgaria seem to be related to Roma and Turkish minorities, but significant, if dynamic, socio-economic cleavages continue to be relevant. The failure of the Bulgarian government and any European mechanism to further integrate the Roma indicates that the ethnic cleavage is frozen will persist; similarly, the more assertive Turkish state seems to dictate that the Turkish-Bulgarian cleavage will remain relevant. The same may be said of the socio-economic cleavage, as three decades after the fall of the communist regime it is still important, despite changing its form somewhat over the years. Representing something of a rarity in the post-communist countries of Europe, the BSP is over 100 years old, albeit with a name change in 1990, and The DPS is almost 30 years old. While others were formed later the endurance of these two parties does suggest that perhaps parties in Bulgaria seem to be able to endure changes in the political landscape and evolving cleavages, particularly notable is the evolution from the early days of transition to the present time. 


\section{Croatia}

Academic research on social cleavages in Croatia identified significant geographical cleavages in Croatia, but it is notable that in general the foundation of modern cleavages can be traced back to the World War II period (Henjak Zakošek - Čular 2013: 443). The mobilisation of social-turned-political divides started, as in other former Yugoslav republics at the beginning of the 1990s. After the transition period during the 90 s and early 2000s, they somewhat changed but the literature and current salient divisions (Henjak - Zakošek Čular 2013) reflect the historical influence mirroring Lipset and Rokkan's conclusions about the long-term persistence of cleavages and the importance of the organisation of divided groups is of utmost importance in this case, due to the dual representation of dividing sides articulated through two mainstream parties which construct the conservative-liberal duality (Franklin 2012).

The religious-secular conflict has been persistently socially and politically active since the World War II period. The conservative versus liberal ideologies present in the beginning of the 1940s when communists and fascists represented the unidimensional pole was politically eradicated by the communist regime in Yugoslavia. Following the unpleasant position of religious organisations under socialism, the catholic church has been actively supporting the national organisations right after Croatia left Yugoslavia and gained independence. Henjak, Zakošek and Čular (2013) highlight the oppression of the religiosity during the socialist time and its strong anti-Catholic views and forced secularisation in Yugoslavia as the reason for the freezing of political divisions even though society was evolving within Yugoslavia. Later, during the early 1990s the Church was actively engaged in promoting Croatian independence and relating itself to the strong Croat nationalist figures, namely the first president Franjo Tuđman. During this time the ideological-cultural cleavage, as Zakošek (1998) identified it, intertwined with the center-periphery division. Croatia has a very homogenous religious structure $-86.28 \%$ being Roman Catholics (Country Reports 2019), nevertheless the level of religiousness is different in different regions, where the East Slavonians are the most religious, while the most developed areas, such as Zagreb and Istra region have the lowest levels of religiosity (Slobodna Dalmacija 2017). The opposing views on the role of the Church in the state affairs, education and moral instruction started in the 1870s, but in modern times, the Church has taken an active role in politics and political preferences are expressed to the masses. In the present, the cleavage is structured on the opposing poles of the religious-traditionalists and secular-modernist concepts of culture incorporated into the duality of Croatian political system, both strongly present and politically articulated between the conservative-right HDZ (Hrvatska Demokratska Zajednica) and secular-leftist SDP (Social Democratic Party). 
Apart from the persistent religious cleavage, Zakošek and Čular (2013) and Henjak, Zakošek, Čular (2013) identified two other territorial-cultural divides as well. Apart from what Siber highlights as the social perspective of the position of Croatia in different organisations, it mainly represents opposing views on how Croatian society should be structured and led (Kuhnle - Sokolović - Rokkansenteret 2003). Henjak, Zakošek and Čular (2013) argue that this cleavage had had a dual character. Firstly, it included the conflict between the Yugoslav states' and republics' centres in different settings, and secondly, the centre periphery divisions in Croatia itself. The inner center-periphery division in modern Croatia represents the division between the southern, coastal region of Dalmatia (Dalmacija) and the northeastern region Slavonia (Slavonija), and the centre - the capital Zagreb region. The first division between these two regions is in the dialect of the Croatian language they use. ${ }^{5}$ The statistics from 2015 show that when completing mandatory courses, Croatian language had the largest percentage of unsatisfactory grades (Slobodna Dalmacija 2015). Nonetheless, the language divides do not only concern the varieties of dialects in Croatian language. Due to the violent past between Croats and Serbs in the northeastern parts of Croatia, society, the government and the opposition had been engaged in a variety of debates about the inclusion of the Serbian Cyrillic alphabet in schools, street signs and other public goods in areas populated with Serbian minority. The anti-Cyrillic protest in 2013 (Al Jazeera 2013) against the bilingualism are another dimension of the territorial and geographical cleavages in Croatia manifest themselves in a variety of ways.

Two main parties, HDZ and the opposition, SDP who held the office from 2008-2014, have been the ultimate mainstream parties since independence from Yugoslavia. After the abandonment of the single party system in Yugoslavia these two parties have gained political momentum and still strongly represent the duality of the Croatian society on the socio-economic pole, but especially regarding the religious cleavage. Croatian parliament has gained certain fragmentation currently consisting of 21 parties. Nevertheless, the left-right divide is still dominated by HDZ-SDP. HDZ, the winner of most mandates in Croatia representing the conservative society lost only in the time when corruption scandals of the government in 2003-2009 left the party weakened and without much electoral support. HDZ and SDP have a high tendency to keep representing the opposing poles of the societal divisions and adoption of the new cleavages through the framework of their party programs. Croatian social divisions have a longer salience and effect on the political sphere than it would be expected by the post-communist country that experienced the economic

5 Dalmatian dialect (Chakavian dialect) greatly differs from the central Kajkavian and Shtokavian dialects. In the Croatian state examination upon completion of high-school, students from Dalmatia have difficulties passing the Croatian language due to significant differences. 
transition. The dual nature of Croatian politics referring to the socio-economic divide successfully encompassed all social conflicts, whether religious-secular, center-periphery and transition-related issues which characterize the fully frozen political party system.

\section{Czech Republic}

In the Czech Republic the cleavage of the form the state should take failed to persist longer than the first democratic election, with economic cleavages being the primary kind in Czech political life, even if parties may somewhat waver on their positions (Mansfeldová 2013). The Czech Republic is a state which, thanks to mass deportations following World War II and the separation of Czechoslovakia into two states, is highly coherent. Given this high level of coherence it is unsurprising that socio-economic issues came to the fore in the development of cleavages. While Hloušek and Kopeček (2008), state that there is an array of secondary cleavages in the Czech Republic, which became more relevant as time went on, such as party attitudes towards European integration and the EU, but that the dominant position of the socio-economic cleavage of transformation has not been threatened.

In 2008, the political parties of the Czech Republic were placed on a socio-economic dimension and revealed the substantial division between the political representation of Czech society (Hloušek - Kopeček 2008: 13). For a country which has historically been one of the most developed in the region, with a low rural population and high levels of economic development, it is not surprising that parties would seek to position themselves in relation to socio-economic cleavages. If socio-economic cleavages are to be expected, and may even represent a moving past of Karasimeonov's temporary (transitory) type of cleavage, then the amount of patronage certainly flies in the face of this. Petr Kopecky (2017) has highlighted this several times, as well as highlighting the fact that Czech parties have come to coalesce into two blocks. These two blocks are led by The Civic Democratic Party (ODS), the main party from the right, and the Czech Social Democratic Party (ČSSD) being the main party of the left (Kopeckỳ Mair - Spirova 2012).

Havlík and Voda (2016) found that between 2010 and 2013 there was a loss in significance of the temporary transition divides and more salient socio-economic cleavage with stable voting patterns, fuelled by the influence of Catholic identification with the right winged the Christian and Democratic Union - Czechoslovak People's Party (KDU-ČSL). They also found that support for the traditional parties was more reliant on cleavages while support for newer parties relied more on socio-economic factors. Nevertheless, the stable right-left positioning prior to 2011 faced threats sooner than expected in the form of the populist movement ANO 2011. Their first important electoral victory 
in 2013 with $18.7 \%$ of the votes and 47 seats in the Chamber of Deputies saw them secure second place behind the ČSSD. The party leader, a Czech millionaire Andrej Babiš quickly gained sympathy through his Action of Dissatisfied Citizens, which he then transformed into ANO 2011 with the focus on tackling down the macroeconomic issues such as unemployment and economic growth, and the aim of efficient public administration. In 2017 elections ANO 2011 won 78 seats in the Chamber of Deputies. ANO has been described as an extreme form of a business-firm party (Kopeček 2016), in speeches and general messages the party and leadership seek to invoke anger over the inefficiency of the public sector and unfairness of privatisation (Havlík 2015). Such issues are still socio-economic in nature, but would typically be associated with countries in an earlier stage of transition and do not confirm to general expectations of the development of political systems within transitioning countries, especially not according to Karasimeonov's typography.

It is clear that the Czech Republic has experienced huge changes in the politically active cleavages over the last three decades. Following the collapse of the communist state there has been concern over the health of Czech democracy, which has been described as under pressure (Pehe 2018), concerns have been raised about populism in the young democracy (Havlík 2015) and there has been questions raised over Euroscepticism (Kaniok - Havlík 2016) and democratic backsliding (Hanley - Vachudova 2018). The clear socio-economic cleavage mildly visible before the 2010s has had doubt cast over it, particularly with the rise of populist, economic-oriented ANO 2011, which might suggest that perhaps Czech divides are in the process of formation of the new economic division. While before this rise the socio-economic cleavage appeared to be frozen, or at least freezing, the rise of a populist party which subverts expectations and invokes what are typically considered transitional cleavages places this in doubt. Cleavages which might have previously been considered stable now appear less so; in addition, the dominant parties before the 2010s with strong socio-economic ideologies, ČSSD and ODS had shown very strong signs of survival despite evolving political situations, this is now also in doubt.

\section{Hungary}

In recent years, Hungary has attracted most attention for its response to the refugee crisis in Europe and its seeming move away from liberalism (Kallius Monterescu - Rajaram 2016), it would be reasonable to expect either modern changes in cleavages and problems in the democratic system based on such concerns. Nonetheless, literature on Hungarian political cleavages lacks the important research ground work. This has also been noticed in the related fields of political studies, namely the voting patterns and electoral studies by Tucker (2002: 279) who couldn't find an obvious explanation for it. 
Tóka and Popa (2013: 295) reflected in the early 1990s period and the failure of the existing parties to clearly define the differences between each other and between the policies advocated for. Hence, they concluded that the anti-communism divide was represented by the small orthodox communist party (MSZMP - Hungarian Socialist Workers' Party) against the liberals (SZDSZ The Alliance of Free Democrats - Hungarian Liberal Party, FIDESZ - The Federation of Young Democrats), and some smaller right-wing parties. Nevertheless, the socio-economic cleavage has never become a major line of conflict as in Poland or Czech Republic (Tóka - Popa 2013: 302). Körösényi as well identified the lack of socio-economic cleavage as demonstrated in Western Europe by Lipset and Rokkan, in Hungary (Körösényi 1993).

In 1995, Evans and Whitefield's (1995) study of Hungarian cleavages identified long-standing conflicts regarding social liberalism, attitudes towards Roma population and the status of Hungarians in neighbouring states. Later in 2000, the same authors studied the social and ideological bases for partisanship in post-communist states. They identified 6 bases for political divisions: age, religiosity and class, being social; while economic liberalism, and social and political liberalism (having two distinguished lines of conflict - Jews and nationalism) reflected the ideological base (Evans and Whitefield, 2000).

Despite the fact that Hungary became a state with vastly reduced ethnic diversity, it did not become a state with absolutely no ethnic diversity and it certainly did not become a state with no ethnic division turned into a persisting cleavage. The existence of large Hungarian minorities in neighbouring states (Romania, Slovakia and Serbia) and a significant Gypsy population within Hungary play into this salience (Evans - Whitefield 1995). Butler (2007) goes even further and relates Hungarian decision to join the EU as means by which neighbouring states could be forced to provide certain rights for ethnic Hungarian minorities. The Movement for a Better Hungary (Jobbik), formed at the beginning of the 2000 s, representing the far-right extreme of the ethnic pole. The national radical and Christian self-characterisation of the movement has gained attention on the mass scale due to its anti-Roma propaganda (Bartlett et al. 2012). The other extreme of ethnic cleavage, represented by minorities in Hungary has been found as openly expressed where authors such as Prelić (2011) characterized minorities as strongly expressing their symbols of identity - language, religion, cultural heritage, artistic creativity - and have their institutional organisations.

Nevertheless, the lack of real left representation, there was no shortage of concern about the level of anti-liberalism in Eastern Europe, and especially the political representation articulating the divides between anti-liberal/conservative/far-right movements to both, less radical parties and ethnic minorities. Hungary is at the forefront of such developments, three decades after the fall of communism the cleavage of nationalism versus liberalism or liberalism versus anti-liberalism very much exists in Hungary (Murer 2015). Hence, the 
ethnic cleavage being an old one, more recent, but still not entirely new is the idea of nationalism-liberalism division in Eastern Europe. The rise of nationalist regimes in several Central Eastern European nations with FIDESZ in Hungary as the most prominent examples of anti-liberalism in the region. The tightening of control over academia (EUA 2018), the media (Freedom House 2017) and the judiciary (Kingsley 2018) all point towards an incredible amount of anti-liberalism. Similar concerns over anti-liberalism are present in Poland, due to increased control over the media (BBC News 2016) and judiciary (Khan - Huber Shotter 2018), and in Slovakia, where there is much concern over the murder of a journalist and his girlfriend in an apparent contract killing (The Guardian 2018). Apart from the anti-liberal agenda, FIDESZ under Orban's leadership successfully encompassed the welfare state and economic issues within its Christian conservative agenda. Tóka and Popa (2013: 308) especially highlight the „newly introduced subsidies “, "hefty tax-cuts for middle to high-income families raising children, "reintroducing the "tuition-free status for about half the university students."

At the aftermath of communism and up until the present time the ethnic cleavage concerning all minorities in Hungary has been socially active but politically expressed only on several occasions for immediate issues at hand. Indeed, the ethnic social conflict in Hungary existed in the past, however we cannot support the statement that it froze due to several aspects. Ethnic identity without arguing represents one of the key aspects of right winged Hungarian parties, from FIDESZ's support for Hungarian minorities in neighbouring countries to Jobbik's radical anti-Roma activities. Nevertheless, the issues surrounding the ethnic conflict have been evolving without the freezing of the political system on the ethnic dimension. Whether or not there exists any political organization capable of expressing such divide is more doubtful due to FIDESZ's successful integration of welfare divides into political party agenda. The second divide concerning the liberal-antiliberal cleavage is too ambiguous to provide the evidence for the clear political cleavage. FIDESZ being one of the oldest parties, having been formed over three decades ago, with increasing anti-liberal policies and the lack of a strong opposition to such stances is not strong enough evidence to conclude that the liberal-antiliberal divides are represented by the mainstream parties today. In the period of establishing Hungarian democracy there was a clear line between socio-economic polarity which transformed into the weak liberal-antiliberal conflict after the disappearance of pro-communist parties. The case of Hungary is representing the strongest evidence for inapplicability of the Lipset-Rokkan framework for identifying cleavages. Social organization around the issues sometimes exist, but it is not politically addressed, and political organization around one line of conflict encompasses other social issues - as argued by Bornschier (2010). Thus, the freezing of the cleavage never occurred in Hungary, but the strongest party successfully managed to incorporate the evolving divides in the society. 


\section{Poland}

Early in the transition Poland was a country in which divides could best be understood through the prism of the attitudes to shock therapy and literature tended to focus on this issue. Peter Murrel (1993) wrote that the divide between radicals and evolutionists was not simply a matter of technical judgements but rather reflected fundamental disagreements about the way human societies function. Around the same time, Simon Johnson, and Marzena Kowalska (1994) were exploring the political economy of shock therapy in Poland. Advocates, most famously Jeffrey Sachs (1995) and Leszek Balcerowicz (1995), advocated strongly the merits of shock therapy, even if Balcerowicz often rejected the term itself. However, once the path which Poland had taken has been justified by the results, a fact which was not lost on Balcerowicz (2019), it seemed that other divides and cleavages would be able to come to the fore.

Despite being often considered to be a rather homogenous nation, where one may expect a country of limited cleavages, the spatial issue is one which is regularly explored in studies (Marcinkiewicz 2018). Many of the geographical cleavages which exist in Poland can be explained through history, which is central to Zarycki's (2015) study The Electoral Geography Of Poland: Between Stable Spatial Structures And Their Changing Interpretations. Poland's history of partition has far-reaching consequences in the present, but the fact that the country was split into three is interesting in that three different areas allowed differing levels of Polishness to exist. The differing levels of freedom were important, but also the differing levels of development can still be seen today. There are a number of ways through which the history of Poland can be seen in the present and not all of them are overtly political. For example the maps which compares the level of railway development in modern Poland with whom the areas were controlled by during partition and show that the level of railway development in the area formerly controlled by the Russian Empire is strikingly lower (Uzar 2008).

Election maps are so commonplace in Poland that there is even a website dedicated to them (wyborynamapie, no date), in recent mainstream media outlets (Skowron 2017) and prominent sociologists (Flis 2014) have particularly noted the geographical divisions between PiS and PO. However, while maps are often produced to illustrate that these historical cleavages are present in the contemporary political system, specifically in electoral results, Stanley argues that they can be misleading:

"Shaded maps can exaggerate the degree of difference at the micro level, and it is notable that even within the regions dominated by PiS, major towns and cities tended to prefer PiS. However, this macro-level distinction has persisted and deepened over three parliamentary and two presidential elections, supporting the contention that 
the Poland A / B divide should be regarded as a 'protocleavage' expressing significant geographical and socio-demographic distinctions." (Stanley 2013: 196)

Ultimately though, geographical divides are present in Poland. They may influence a plethora of other cleavages, but there can be no doubt that they do exist. Furthermore, they particularly exist in the minds of Polish people, a fact which is perhaps more important than any other consideration.

As previously noted Poland is a highly homogenous country, one which does not seem to be a prime candidate for the existence of religious cleavages. However, the divide between Catholics and non-Catholics is an important cleavage (Deegan-Krause 2013a). In fact, it may be an area of future development. This can be exhibited in many ways, but the debate between how Catholic the official state organisations and laws should rarely be framed in a pro-Catholic/anti-Catholic context. On the contrary it tends to be framed as an issue of secularism versus morality. Even within this religious context the cleavage has been most clearly evident in legislation which focuses on women, with abortion being the prime example. The Financial Times reported that the mood had turned against the Catholic Church and during protests such overtly anti-Catholic signs, notable for their being preferred to anti-government signs, read: „I decide about religion, not religion about me' and 'My uterus is not your chapel" (Graff 2018). Media outlets, especially foreign media outlets, describing public opinion is something which ought to be treated with some scepticism. However, in this case it does seem to be backed up by domestic figures from Poland. In 2011, 62\% approved of the activities of the Roman Catholic Church, but in 2018 that had fallen to 54\% (Żurek et al. 2018). If trends continue then the religious cleavages of Poland may well become more salient. This is a cleavage which the governing party Law and Justice (PiS) have successfully relied upon, especially in the fact of a fragmented and disorganised opposition.

In terms of the age of this cleavage there are issues in judging due to the context of church versus state (one of Lipset and Rokkan's cleavages) being drastically changed from communist times. Therefore, it seems that geographical cleavages are historic cleavages which appears to be frozen, but church versus state in the post-communist sense seems to be, as of yet, one merely of potential. In terms of whether a persistence in the ideological axis is present despite evolving cleavages, it is clear that this is not the case. Moreover, the intense personification of leaders and their parties would make most question whether this is possible in the coming decades. The Kaczynski domination of PiS has continued since the foundation of the party in 2001 and despite the death of one of the twins, but this phenomenon is cross party and cross political spectrum as Robert Biedroń's domination of Wiosna and Janusz Korwin-Mikke of Wolność illustrate. 


\section{Romania}

Research studies of the Romanian case tend to predominantly focus on the ethnic divisions and well-known sizeable number of ethnic minorities. Due to the peculiar Romanian political past, Crowther highlighted the inapplicability of cleavage analysis to Romania due to the lack of a strong and well-developed civil society (Crowther - Suciu 2013: 363). It would be reasonable to expect the sizeable Hungarian minority to form a considerable social cleavage and demand the political representation of such in Romania. Indeed, the division between ethnic Romanians and ethnic Hungarians is noted by many authors and is the centre of much discussion. Romanian and Hungarian nationalistic drives did manage to mobilise important sections of the public belonging to both ethnic groups, some deemed the confrontation between Romanian and Hungarian nationalists to not be based on a major interethnic cleavage (Lawson - Römmele - Karasimeonov 1999), while Pisciotta in her study of the center-periphery cleavage in East and Central Europe highlights the electoral weight of the ethnic and nationalist parties in Romania in 2000-2004 (Pisciotta 2016: 209). As noted by Stroschein (2001), the most successful titular party could be found in Romania. Therefore, while some may shy away from calling this division a fully-fledged cleavage it is a notable divide in Romanian politics, which more than in neighbouring countries is reflected in the party choice available to citizens of Romania. While the presence of nationalist parties in any size, shape or form, may be expected to cause divisions, it does seem that Romania has parties which ably represent both ethnic minorities and minority views (Pisciotta 2016).

Before becoming a member of the EU, Romanian society was framed on the authoritarian-democratic divide, mostly due to the inability to reject all communist aims (Dryzek - Holmes 2002: 250-251) and by the electoral victory of Vadim Tudor in 2000 who in the period prior to the accession to the EU didn't favour member status for Romania and came from the far right Greater Romanian Party (PRM). The PRM's irredentist character reflected through the aspirations of returning the borders of Greater Romania by reuniting all the Romanian minorities populating the regions in Moldavia and the southern region of Hungary (Pisciotta 2016: 209). In the more mainstream, centre ground of Romanian politics, there are parties which represent catch all policies and centrist ideas. The primary example of which was at one point considered to be the Liberal Democratic Party (PDL), which later merged with the National Liberal Party (PNL). However, the centre ground is occupied by multiple parties which are vote centric parties - often resulting in centrist policies which may not always appear logically compatible (Crowther - Suciu 2013). Moreover, these parties are often deemed to be leader centric and top-down organised. This perhaps reflects the weak nature of Romanian civil society, at least at the 
moment of communist demise. Agh argues that the actual conflict between communist and anticommunist parties led to the emergence of the new multi-party and first generation parties (Lane - Pennings 2003: 211). Perhaps unexpectedly, especially given the fact that Romania is rarely viewed as an archetypical post-communist success story, the three main communist party-derived formations in Romania are much more pro free market than could be expected, even more so than the population average (Berglund - Ekman 2010). This goes to show that even those parties which most would expect to exist outside of, and be a challenge to, the mainstream are located closer to the centre than in many post-communist transitioning countries.

The Romanian ethnic divides and political organisation around minority rights cannot be ignored, ethnic divisions have been present in the aftermath of the communist era and do persist today. Nevertheless, their salience can be brought to question if we speak about the actual freezing of the ethnic cleavage. The loudest ethnic party and the clear opposition to PRM, the Democratic Alliance of Hungarians in Romania (UDMR) has been advocating for the greater autonomy of the regions, namely because most Hungarians populate the Transylvanian region. Pisciotta (2016) stresses here the substantial losses of UDMR and other ethnic parties due to the Social Democratic Party (PSD) and PNL victories prior to 2016. On the other hand, smaller divides resulting from the transition period to market economy and resilience to full democracy have not been active for a substantial amount of time. Mainstream parties which have been constant in their stance to cleavages do not exist in Romania. Most of them seem less certain, as they jostle around the centre ground, without those which seek to represent the opposing poles in the society which tempts the conclusion that social divisions are not active enough to stimulate the political alignment.

\section{Slovakia}

The issue of ethnic cleavages were discussed in the Hungarian context, but once again Hungarians are also involved in ethnic cleavages across the border in Slovakia (as in Romania). In the population census in 2011, 8.5\% of Slovak population declared themselves as Hungarians, the second biggest ethnic group in Slovakia (Statistical Office of the Slovak Republic 2011). Above all, it is notable that studies have identified the ethnic Hungarians in Slovakia as voting according to ethnicity above all else (Henderson 1999). Some parties, such as the Slovak National Party, defined themselves as antagonistic to the interests of the neighbouring Hungarian and the Hungarians which reside in Slovakia (Whitefield - Evans 1999). Overall though, it is noted that while this cleavage is deep it has a small direct impact on party preference, since Hungarians comprise only one ninth of Slovakia's population (Deegan-Krause 2013b). However, the 
overall impact of the Hungarian minority should not be underestimated purely due to the relatively small size of the minority.

„The depth of the cleavage between Hungarians and Slovaks ensured its endurance, but did guarantee its relevance. Certainly Hungarian parties played a crucial role in the formation of some governments but the presence of a strong national divide within the Slovak population limited the Hungarians' choice of coalition partners and prevented them from any plausible kingmaker role. Of course the intra-Slovak debate about national identity is in no small part the result of the existence of a significant Hungarian minority within Slovakia's population. So even though the cleavage between Hungarians and Slovaks itself remained politically relatively marginal, it helped to fuel the national competition among Slovaks which remained pivotal during the 1990s and seemed poised to return to prominence at times during the 2000s." (Deegan-Krause 2013b: 275)

It seems that in a country with relatively few cleavages, due in large part to separation from a markedly different partner, the ethnic issue was one which never went away even if it did not develop into a more divisive issue or politically hot topic.

In the Czech case, the loss of national minorities were somewhat to their advantage, in the Slovak case it has come to represent one of their biggest divides. This is especially so after the defeat of Vladimír Mečiar's ruling party People's Party - Movement for a Democratic Slovakia, however this may no longer be the case as Most-Híd have both become the largest Hungarian minority party in Slovakia and have also moved to represent Hungarians and Slovaks in Slovakia (Terry 2014). While voting is still mostly on ethnic lines, it does perhaps represent a break in the future whereby the cleavage could become less salient, this may simply be a case of the lack of representation of the Hungarian minority but the continued lack of success of the more extreme Party of the Hungarian Community suggests that this is not the case. Szabó and Tátrai (2016: 205) highlighted the fact that out of the three biggest ethnic minorities of Slovakia - Hungarians, Roma, and Rusins/Ukrainians - only the Rusins/ Ukrainians have not organized their own ethnic party. Despite the existence of Roma parties, low participation of the minority in the elections has been characterized as the main reason for poor electoral representation, despite the size of the ethnic group. Szabó and Tátrai (2016: 206) and Petőcz (2009) reported that Roma voters supported mostly the national-populist and etatist-leftist parties in areas which marginalized Roma or where they constituted the local majority; and Hungarian parties in regions where Hungarian-speaking Roma live.

Studies have indicated that Slovakia's post-communist transition has been anything but straightforward (Goldman 1999; Deegan-Krause 2012), which has implications for cleavages, but for the entire democratic system. While studying 
cleavages in 13 post-communist countries, Rohrschneider (2009: 295) came to the conclusion that the most salient issue divides in Slovakia, Estonia, Slovenia and Ukraine is the democracy dimension. Jointly with the center-periphery related conflicts - religion and regionalism - social rights and communist legacy have been considered as the driving force of Slovakian political positioning in the 2000s (Rohrschneider 2009: 311). Contrary findings to the most significant cleavage in Slovakia were given by Evans and Whitefield (1998:133) in the study of political cleavages in the Czech Republic and Slovakia, where the ethnic dimension without doubt had the strongest effect on the political positioning.

While the ethnic cleavage is long-standing, it is difficult to conclude that it is frozen as one of the major cleavages of Slovakia is losing some salience, although perhaps it is a positive for an ethnic cleavage to lose salience. Cleavages in Slovakia do not seem stable or secure to any notable degree. Directly related to this reality is the changeable party situation which has led to the ruling party of the early transitional period no longer existing (Minarechová 2012) and extreme change in the makeup of parties representing the Hungarian minority (Rybár 2017), as noted in the beginning, one of the more stable divides in Slovakia. Therefore, there is no persistence in the ideological axis despite evolving cleavages.

\section{Conclusions and implications}

This article has sought to review the research studies of political cleavages in 6 post-communist countries of Europe which have transitioned to democracy. In many cases the continued existence of traits from the legacy of the pre-communist history in nations where religious divisions existed before a communist regime was established were found to still be present, as were societal divisions which survived under the communist regimes and represented a driving force for political organisation upon communist demise were expected to exist to this day. Moreover, they seemed to be more stable and more likely to be frozen than those which were more recent developments. This is the case in Croatia, with strong historical cleavages, and Bulgaria, Hungary, Romania and Slovakia, in terms of their ethnic divisions. Even in Poland the historical cleavage of geographical difference persists long after many thought it might have.

Conversely, those cleavages which developed since the fall of communism seemed less secure and more prone to change. With even quite secure and long-standing cleavages seemingly open to large and unexpected changes, e.g. the socio-economic cleavage in the Czech Republic. Returning to the theme of attempting to bridge the gap between Lipset and Rokkan, it seems that frozen cleavage theory can be applied to post-communist Europe only in the case of historical divides whose salience predates the communist regimes. The expected transitional (economic) cleavages have mostly been incorporated into the 
political agendas of the mainstream parties. Hungary and Czech Republic are the clear outliers to this assumption - Hungary with one of the oldest parties articulating new divides and not, as might have been expected, aligning itself fully with the persistent cleavage; and Czech Republic's new populist challenger which disturbed the freezing of the socio-economic cleavage after almost two decades of the unidimensional political space.

This raises the question, especially for future studies of post-communist world, whether or not contemporary politics has fundamentally changed and frozen cleavages represent a relic, or whether or not in the coming decades more stability and frozen cleavages can be expected to be found in post-communist Europe. Moreover, as the post-communist countries move further and further away from their communist past questions will arise over which divides and cleavages are rooted in this past. Furthermore, the answer to this should be expected to become increasingly less clear with the passage of time. Given that the increasingly changeable nature of Western politics, future studies may be more inclined to view the changeable party system in post-communist Europe through a uniform lens with caveats about communist pasts and the uniqueness of this experience.

\section{References}

Al Jazeera (2013): Croatians protest against Cyrillic signs | Croatia News. Available at: https:// www.aljazeera.com/news/europe/2013/04/201347172816369285.html (5 September 2019).

Anckar, Carsten (2008): On the Applicability of the Most Similar Systems Design and the Most Different Systems Design in Comparative Research, International Journal of Social Research Methofology 11(5):389-401. doi: 10.1080/13645570701401552.

BBC News (2016): Polish government to control state media, 7 January. Available at: https:// www.bbc.com/news/world-europe-35257105 (6 December 2018).

Balcerowicz, Leszek (1995): Socialism, Capitalism, Transformation. Budapest: Central European University Press.

Balcerowicz, Leszek (1994): Economic Transition in Central and Eastern Europe: Comparisons and Lessons. The Australian Economic Review 27(1): 47-59. https://doi.org/10.1111/j.1467-8462.1994. tb00824.x.

Bartlett, Jamie, Jonathan Birdwell, Péter Krekó, Jack Benfield, and Gabor Gyori (2012): Populism in Europe: Hungary.

Bartolini, Stefano, and Peter Mair (2007): Identity, competition and electoral availability: the stabilisation of European electorates 1885-1985. ECPR Press.

Beissinger, Mark R., and Stephen Kotkin (eds) (2014): Historical legacies of communism in Russia and Eastern Europe. New York: Cambridge University Press. 
Bendix, Reinhard (1952): Social Stratification and Political Power. American Political Science Review 46(2): 357-375. doi: 10.2307/1950834.

Berelson, Bernard R., Paul F. Lazarsfeld, William N. McPhee, and William N. McPhee (1954): Voting: A study of opinion formation in a presidential campaign. University of Chicago Press.

Berglund, Sten, and Joakim Ekman (2010): Cleavages and Political Transformations. doi: 10.1007/978-0-387-88199-7_5.

Bideleux, Robert, and lan Jeffries (2007): The Balkans: a post-communist history. 1st ed. Milton Park, Abingdon, Oxon; New York: Routledge.

Bornschier, Simon (2010): Cleavage politics and the populist right. Temple University Press.

Brzezinski, Zbigniew (1957): Communist Ideology and Power: From Unity to Diversity. The Journal of Politics 19(4): 549-590. doi: 10.2307/2126952.

Butler, Eamonn (2007): Hungary and the European Union: The Political Implications of Societal Security Promotion. Europe-Asia Studies 59(7): 1115-1144.

Campbell, Angus, Philip E. Converse, Warren E. Miller, and E. Donald (1960): Stokes. The American Voter, Ann Arbor, Ml: University of Michigan Press.

Carvalho, João, and Didier Ruedin (2018): The positions mainstream left parties adopt on immigration: A cross-cutting cleavage? Party Politics: 1354068818780533.

Cheresheva, Mariya (2017): Turkey's Hand in Bulgarian Election Angers Sofia. Balkan Insight, 20 March. Available at: https://balkaninsight.com/2017/03/20/turkey-s-hand-in-bulgarian-election-angers-sofia-03-19-2017/ (6 August 2019).

Country Reports (2019): Countries of the World - CountryReports, Country reports: Croatia. Available at: https://www.countryreports.org/?countryid=62 (14 April 2019).

Crowther, William, and Oana-Valentina Suciu (2013): Romania. In Berglund, S. (ed.) The handbook of political change in Eastern Europe. Third edition. Northampton, MA: Edward Elgar Pub. 369-406.

Cviklova, Lucie (2015): Direct and indirect racial discrimination of Roma people in Bulgaria, the Czech Republic and the Russian Federation. Ethnic and Racial Studies 38(12): 2140-2155. doi: 10.1080/01419870.2015.1042892.

Dahl, Robert A. (1956): A preface to democratic theory. University of Chicago Press.

Deegan-Krause, K. (2012): Populism, democracy, and nationalism in Slovakia, Populism in Europe and the Americas: Threat or Corrective for Democracy. 182-204.

Deegan-Krause, Kevin (2013a): Full and Partial Cleavages, in Berglund, S. (ed.) The handbook of political change in Eastern Europe. Third edition. Northampton, MA: Edward Elgar Pub. 35-50.

Deegan-Krause, Kevin (2013b): Slovakia. In Berglund, S. (ed.) The Handbook of Political Change in Eastern Europe. Third edition. Northampton, MA: Edward Elgar Pub.

Dryzek, John S., and Leslie Holmes (2002): Postcommunist democratization: political discourses across thirteen countries. New York: Cambridge University Press (Theories of institutional design).

Dupré, Jean-François (2018): National identity politics and cultural recognition: the party system as context of choice. Identities 25(1): 67-84. 
EUA (2018): EUA denounces dismantling of university autonomy in Hungary. Available at: https://eua.eu/news/182:eua-denounces-dismantling-of-university-autonomy-in-hungary. html (9 December 2018).

Elster, Jon, Claus Offe, Ulrich K. Preuss, Frank Boenker, Ulrike Goetting, and Friedbert W. Rueb (1998): Institutional design in post-communist societies: Rebuilding the ship at sea. Cambridge University Press.

Evans Geoffrey, and Stephen Whitefield (2000): Explaining the Formation of Electoral Cleavages in Postcommunist Democracies. In Klingemann, H.D., E.Mochmann, and K. Newton, Elections in Central and Eastern Europe: The First Wave. 36-70. Berlin: Ed. Sigma.

Evans, Geoffrey, and Stephen Whitefield (1995): Social and Ideological Cleavage Formation in Post-Communist Hungary. Europe-Asia Studies 47(7): 1177-1204.

Evans, Geoffrey, and Stephen Whitefield (1998): The Structuring of Political Cleavages in Post-Communist Societies: the Case of the Czech Republic and Slovakia. Political Studies 46: 115-139.

Flis, Jarosław (2014): Maj | 2014 | Zygzaki władzy, 14 May. Available at: http://jaroslawflis.blog. tygodnikpowszechny.pl/2014/05/ (13 August 2019).

Franklin, Mark N. (2012): Electoral change: responses to evolving social and attitudinal structures in western countries. Colchester: ECPR Press.

Freedom House (2017): Hungary. Available at: https://freedomhouse.org/report/freedom-press/2017/hungary (9 December 2018).

Freedom House (2018): Nations in Transit 2018: Confronting Illiberalism. Available at: https:// freedomhouse.org/report/nations-transit/nations-transit-2018 (6 August 2019).

Freedom House (2019): Freedom in the World 2019 Map.Available at: https://freedomhouse. org/report/freedom-world/freedom-world-2019/map (6 August 2019).

Fukuyama, Francis (2006): The end of history and the last man. Simon and Schuster.

Ganev, Venelin I. (2004): History, Politics, and the Constitution: Ethnic Conflict and Constitutional Adjudication in Postcommunist Bulgaria. Slavic Review 63(1): 66-89. doi: 10.2307/1520270.

Gawthorpe, Steven (2010): Unstable Membership: Bulgaria, Corruption, and Policy of the European Union.

Goldman, Minton F. (1999): Slovakia since independence: a struggle for democracy. Westport, Conn: Praeger.

Graff, Agnieszka (2018): Poland's abortion ban is a test case for the Catholic Church, Financial Times. Available at: https://www.ft.com/content/d3d92b9e-3348-11e8-b5bf-23cb17fd1498 (15 December 2018).

Hanley, Seán, and Milada Anna Vachudova (2018): Understanding the illiberal turn: democratic backsliding in the Czech Republic. East European Politics 34(3): 276-296.

Havlík, Vlastimil (2015): The economic crisis in the shadow of political crisis: The rise of party populism in the Czech Republic, European Populism in the Shadow of the Great Recession. 199-216. 
Havlík, Vlastimil, and Petr Voda (2016): The rise of new political parties and re-alignment of party politics in the Czech Republic. Acta Politologica 8(2): 119-144.

Henderson, Karen (1999): Problems Of Democratic Consolidation In The Slovak Republic, Társadalom és gazdaság Közép- és Kelet-Európában / Society and Economy in Central and Eastern Europe 21(3): 141-178.

Henjak, Andrija, Nenad Zakošek, and Goran Čular (2013): Croatia, in Berglund, S. (ed.) The handbook of political change in Eastern Europe. Third edition. Northampton, MA: Edward Elgar Pub. 443-480.

Hloušek, V. and Kopeček, L. (2008): Cleavages in the Contemporary Czech and Slovak Politics Between Persistence and Change', East European Politics \& Societies 22(3): 518-552. doi: $10.1177 / 0888325408315833$.

Hooghe, Liesbet, Gary Marks, Arjan H. Schakel, Sandra Chapman Osterkatz, Sara Niedzwiecki, and Sarah Shair-Rosenfield (2016): Measuring regional authority: A postfunctionalist theory of governance. Oxford University Press.

Horowitz, Donald L. (1985): Ethnic groups in conflict. Berkeley, Calif.: Univ. of California Pr.

Johnson, Simon, and Marzena Kowalska. Poland: The Political Economy of Shock Therapy. Voting for Reform. Democracy, Political Liberalization, and Economic Adjustment, Oxford University Press, Oxford, 1994. 185-241.

Kallius, Annastiina, Daniel Monterescu, and Prem Kumar Rajaram (2016) Immobilizing mobility: Border ethnography, illiberal democracy, and the politics of the "refugee crisis" in Hungary. American Ethnologist, 43(1): 25-37.

Kaniok, Petr, and Vlastimil Havlík (2016): Populism and euroscepticism in the Czech Republic: Meeting friends or passing by?. Romanian J. Eur. Aff. 16: 20.

Karasimeonov, Georgi, and Milen Lyubenov (2013): Bulgaria. In Berglund, S. (ed.) The handbook of political change in Eastern Europe. Third edition. Northampton, MA: Edward Elgar Pub. 407-442.

Khan, Mehreen, Evon Huber, and James Shotter (2018): Poland faces European backlash over judicial reforms, Financial Times. Available at: https://www.ft.com/content/ef3b5420-7f6011e8-bc55-50daf11b720d (6 December 2018).

Kingsley, Patrick (2018): After Viktor Orban's Victory, Hungary's Judges Start to Tumble, The New York Times, 15 October. Available at: https://www.nytimes.com/2018/05/01/world/europe/ hungary-viktor-orban-judges.html (9 December 2018).

Klingemann, Hans-Dieter, Richard I. Hofferbert, and lan Budge (1994): Parties, policies, and democracy. Westview Press.

Kopecký, Petr (2017): The rise of the power monopoly: Political parties in the Czech Republic, in Post-Communist EU Member States. Routledge. 139-160.

Kopecký, Petr, Peter Mair, and Maria Spirova (2012): Party patronage and party government in European democracies. Oxford University Press.

Kopeček, Lubomír (2016): I'm Paying, So I Decide Czech ANO as an Extreme Form of a Business-Firm Party, East European Politics and Societies 30(4): 725-749. 
Kornai, János (1996): Paying the Bill for Goulash Communism: Hungarian Development and Macro Stabilization in a Political-Economy Perspective. Social Research 63(4): 943-1040.

Kostova, Dobrinka (2016): Report on Bulgaria: Elites' Europeanness and their Trust in Institutions, $<p>$ Historical Social Research / Historische Sozialforschung Vol. 41, No. 4(2016): Volumes per year: 1</p>-. doi: 10.12759/hsr.41.2016. 4. 239-253.

Kuhnle, Stein, Džemal Sokolović, and Rokkansenteret (2003): The Balkans: searching for solutions.

Körösényi, András (1993): The Crisis Of Marxism—leninish — Xiii: Stable Or Fragile Democracy? Political Cleavages And Party System In Hungary. Government and Opposition 28(1): 87-104.

Lambrev, Veselina, Bozhin Traykov, and Anna Kirova (2018): Constructing Roma students as ethnic "others" through orientalist discourses in Bulgarian schools. International Studies in Sociology of Education 27(1): 23-41. doi: 10.1080/09620214.2018.1425894.

Lane, Jan-Erik, and Paul Pennings (2003): Comparing party system change. Routledge.

Lawson, Kay, Andrea Römmele, and Georgi Karasimeonov (eds) (1999) Cleavages, parties, and voters: studies from Bulgaria, the Czech Republic, Hungary, Poland, and Romania. Westport, Conn: Praeger.

Lazarsfeld, Paul Felix, Bernard Berelson, and Hazel Gaudet (1944): The people's choice.

Lijphart, Arend (1971): Comparative Politics and the Comparative Method. American Political Science Review 65(3): 682-693. doi: 10.2307/1955513.

Lijphart, Arend, Ronald Rogowski, and R. Kent Weaver (2010): Separation of powers and cleavage management. In Weaver, R. K. and Rockman, B.A. (eds) Do institutions matter?: government capabilities in the United States and abroad. Brookings Institution Press. 302-344.

Lipset, Seymour Martin, and Stein Rokkan (1967): Party Systems and Voter Alignments: Cross-national Perspectives. New York: Free Press.

Mair, Peter (1997) Party system change: approaches and interpretations. Oxford University Press.

Mansfeldová, Zdenka (2013): The Czech Republic. In Berglund, S. (ed.) The handbook of political change in Eastern Europe. Third edition. Northampton, MA: Edward Elgar Pub. 217-254.

Marcinkiewicz, Kamil (2018): The Economy or an Urban-Rural Divide? Explaining Spatial Patterns of Voting Behaviour in Poland. East European Politics and Societies: and Cultures 32(4): 693-719. doi: 10.1177/0888325417739955.

Minarechová, Radka (2012): Party ends for Mečiar - spectator.sme.sk. Available at: https:// spectator.sme.sk/c/20043323/party-ends-for-meciar.html (5 September 2019).

Moreno, Alejandro (2015): Value Cleavages Revisited. In Gunther, R. et al. (eds) Voting in old and new democracies. New York: Routledge is an imprint of the Taylor \& Francis Group, an Informa business, pp.99-149.

Mrak, Mokmir, and Matija Rojec (2013): EU Accession as an Instrument for Speeding Up Transition. In Hare, G. and Turley, G. (eds) Handbook of the economics and political economy of transition. Abingdon, Oxon; New York: Routledge (Routledge international handbooks).

Murer, Jeffrey Stevenson (2015): The rise of Jobbik, populism, and the symbolic politics of illiberalism in contemporary Hungary. The Polish Quarterly of International Affairs 24(2): 79-102. 
Murrell, Peter. What Is Shock Therapy? What Did It Do in Poland and Russia? Post-Soviet Affairs 9(2): 111-40.

Mylonas, Harris (2013): Revisiting the Link: Politicizing Religion in Democratizing Countries. Harvard International Review 34(4): 48-52.

Nenkova, Antoaneta (2013): Millions don't help Roma integration in Bulgaria | DW | 21. 03. 2013, DW.COM. Available at: https://www.dw.com/en/millions-dont-help-roma-integration-in-bulgaria/a-16691459 (7 August 2019).

Nie, Norman H., John R. Petrocik, and Sidney Verba (1999): The changing American voter. To Excel:

Pedersen, Mogens N. (1979): The Dynamics Of European Party Systems: Changing Patterns Of Electoral Volatility', European Journal of Political Research, 7(1), pp.1-26. doi: 10.1111/j.14756765.1979.tb01267.x.

Pehe, Jiri (2018): 'Czech Democracy Under Pressure. Journal of Democracy 29(3): 65-77.

Petőcz, Kálmán (2009): National Populism and Electoral Behaviour. In Petőcz, K., ed. National populism and Slovak-Hungarian relations in Slovakia 2006-2009. Šamorín (Forum Minority Research Institute). 99-165.

Pisciotta, Barbara (2016): The Center-Periphery Cleavage Revisited: East and Central Europe from Postcommunism to Euroscepticism. Nationalism and Ethnic Politics 22(2): 193-219, DOI: 10.1080/13537113.2016.1169063.

Posner, Daniel N. (2005): Institutions and ethnic politics in Africa. Cambridge; New York: Cambridge University Press (Political economy of institutions and decisions).

Prelić, Mladena (2011): Conceptualization And Symbolization Of Ethnic Identity: Serbs In Hungary. Český lid 98(3): 239-260.

Rohrschneider, Robert, and Stephen Whitefield (2009): Understanding Cleavages in Party Systems: Issue Position and Issue Salience in 13 Post-Communist Democracies. Comparative Political Studies 42(2): 280-313. doi: 10.1177/0010414008325285.

Rohrschneider, Robert, and Stephen Whitefield. (2009): Understanding Cleavages in Party Systems: Issue Position and Issue Salience in 13 Post-Communist Democracies. Comparative Political Studies 42(2): 280-313.

Rybář, Marek (2017): Old parties and new: changing patterns of party politics in Slovakia. In: Post-Communist EU Member States. Routledge, pp.161-190.

Sachs, Jeffrey D. (1995): Shock Therapy in Poland: Perspectives of Five Years.

Schattschneider, Elmer Eric (1975): The semisovereign people: A realist's view of democracy in America. Wadsworth Publishing Company.

Schimmelfennig, Frank, and Ulrich Sedelmeier (2004): Governance by conditionality: EU rule transfer to the candidate countries of Central and Eastern Europe. Journal of European public policy 11(4): 661-679.

Skowron, Grzegorz (2017): PiS prawie nie traci, ale PO trochę zyskuje. Małopolska popiera PiS i Andrzeja Dudę, Dziennik Polski. Available at: https://dziennikpolski24.pl/pis-prawie-nie-traci-ale-po-troche-zyskuje-malopolska-popiera-pis-i-andrzeja-dude/ar/11962680 (13 August 2019). 
Slobodna Dalmacija (2015): Rezultati državne mature: 95 učenika sa stopostotnim rezultatom ispita, 249 ih palo > Slobodna Dalmacija. Available at: https://www.slobodnadalmacija.hr/ novosti/hrvatska/clanak/id/280295/rezultati-drzavne-mature-95-ucenika-sa-stopostotnim-rezultatom-ispita-249-ih-palo (14 April 2019).

Slobodna Dalmacija (2017): Najmanje religiozni najrazvijeniji dijelovi Hrvatske, a trećina ne prihvaća ono što kaže Crkva nego se ponaša kao 'sam svoj' vjernik > Slobodna Dalmacija. Available at: https://www.slobodnadalmacija.hr/novosti/hrvatska/clanak/id/467136/najmanje-religiozni-najrazvijeniji-dijelovi-hrvatske-a-trecina-ne-prihvaca-ono-sto-kaze-crkva-nego-se-ponasa-kao-sam-svoj-vjernik (14 April 2019).

Stanley, Ben (2013): Poland. In: Berglund, S. (ed.) The handbook of political change in Eastern Europe. Third edition. Northampton, MA: Edward Elgar Pub. 167-216.

Statistics Poland (2019): Statistics Poland / Basic data. Available at: https://stat.gov.pl/en/basic-data/ (4 September 2019).

Stroschein, Sherrill (2001): Measuring Ethnic Party Success in Romania, Slovakia, and Ukraine. Problems of Post-Communism 48(4): 59-69. doi: 10.1080/10758216.2001.11655943.

Sturm, Jan-Egbert, and Jakob De Haan (2015): Income Inequality, Capitalism, and Ethno-Linguistic Fractionalization. The American Economic Review 105(5): 593-597.

Szabó, Balázs, and Patrik Tátrai (2016): Regional And Social Cleavages In The Slovak Elections After The Change Of The Regime. Geographical Journal 68 (3): 195-212.

Terry, Chris (2014): Most-Hid, The Democratic Society. Available at: https://www.demsoc. org/2014/05/19/most-hid/ (6 September 2019).

The Guardian (2018): Slovak journalist's murder was contract killing, says prosecutor | World news | The Guardian. Available at: https://www.theguardian.com/world/2018/mar/26/slovak-journalists-was-contract-killing-says-prosecutor (16 December 2018).

Tucker, Joshua A. (2002): The First Decade of Post-Communist Elections and Voting: What Have We Studied, and How Have We Studied It? Annual Review of Political Science 5(1): 271-304.

Tóka, Zdenka, and Sebastian Popa (2013): Hungary. In: Berglund, S. (ed.) The handbook of political change in Eastern Europe. Third edition. Northampton, MA: Edward Elgar Pub, 291-338.

Uzar, Raf (2008): Age-old Legacy. Available at: https://uzar.wordpress.com/2008/04/26/age-old-legacy/ (10 December 2018).

White, Stephen, Richard Rose, and Ian McAllister (1997): How Russia Votes. Chatham House Publishers.

Whitefield, Stephen, and Geoffrey Evans (1999): Political Culture versus Rational Choice: Explaining Responses to Transition in the Czech Republic and Slovakia. British Journal of Political Science 29(1): 129-154.

Zakošek, Nenad (1998): Ideološki rascjepi i stranačke preferencije hrvatskih birača. Birači i demokracija: utjecaj ideoloških rascjepa na politički život, Alinea, Zagreb. 11-50.

Zarycki, Tomasz (2015): The Electoral Geography Of Poland: Between Stable Spatial Structures And Their Changing Interpretations. Erdkunde 69(2): 107-124. 
wyborynamapie (no date): Wybory w Polsce - Wyniki na Mapie. Available at: http://www.wyborynamapie.pl/ (13 August 2019).

Öztürk, Ahmet Erdi, and Semiha Sözeri (2018): Diyanet as a Turkish Foreign Policy Tool: Evidence from the Netherlands and Bulgaria. Politics and Religion, 11(3): 624-648. doi: 10.1017/ S175504831700075X.

Żurek, Iwona, Paweł Żebrowski, Maciej Puchłowski, and Krzysztof Markowski (2018): CBOS: Polacy najlepiej oceniają działalność policji, wojska i Kościoła katolickiego, www.gazetaprawna.pl. Available at: http://www.gazetaprawna.pl/artykuly/1111626,cbos-polacy-najlepiej-oceniaja-dzialalnosc-policji-wojska-i-kosciola-katolickiego.html (15 December 2018).

Ena Redžić, Ph.D. studied Economics at the University of Sarajevo and continued her studies in Public administration and Politics at NRU Higher School of Economics in Moscow. Email: eredzic@hse.ru

Judas Everett, Ph.D. studied International Relations at the Aberystwyth University, Global Studies at the University of Wroclaw and Politics at NRU Higher School of Economics in Moscow. Email: jeverett@hse.ru 